\title{
Student Performance in Undergraduate Economics Courses
}

\author{
Kevin J. Mumford \\ Department of Economics \\ Purdue University \\ 100 S. Grant Street \\ West Lafayette, IN 47907 \\ (765) 496-6773 \\ mumford@purdue.edu
}

\author{
Matthew W. Ohland \\ Department of Engineering Education \\ Purdue University \\ 701 W. Stadium Road \\ West Lafayette, IN 47907 \\ (765) 496-1316 \\ ohland@purdue.edu
}

December 2010

\begin{abstract}
We use the MIDFIELD database, a collection of all undergraduate student records from eight large public universities from 1990 to 2003, to study the performance of students in two economics courses: principles of microeconomics and intermediate microeconomics. We analyze how economics course enrollment, performance, and student characteristics have changed over the 14 year period. This paper also documents the selection and performance of students into the economics major, with a focus on students who transfer into economics from other math-intensive majors.
\end{abstract}




\section{Introduction}

Few previous studies have investigated the characteristics and performance of students in undergraduate economics courses. Student academic records are confidential and protected by the Family Educational Rights and Privacy Act (FERPA). This law requires researchers to either obtain written consent from each individual student or to have a school official strip the student academic records of identifying information. The confidentiality of student records and obstacles in working with school officials from other institutions makes it difficult to obtain administrative data. Thus researchers have primarily relied on survey data to address questions related to undergraduate economics courses.

Bosshardt and Watts (2008) use the U.S. Department of Education Baccalaureate and Beyond data which contains about 8,000 undergraduate student transcripts from the 19921993 academic year graduates. Siegfried (2000) uses a survey conducted at the departmentlevel with responses from 236 economics departments. Other studies, including Salemi and Eubanks (1996) and Dynan and Rouse (1997), use student academic records from a single university. A few other studies, including Jensen and Owen (2000) and Allgood et al. (2004), have used surveys of students in economics courses from multiple schools. However, the sample sizes have been small.

In this paper, we use data from the Multiple-Institution Database for Investigating Engineering Longitudinal Development (MIDFIELD), a collection of student academic records for all undergraduate students from eight large public universities in the South and Midwest from 1990 to 2003 . A disadvantage of using this data is that it is not nationally representative, but 
the advantage is that this dataset contains complete academic transcripts for the 245,643 students who completed an economics course at one of the participating universities.

The large amount of student data over the 14-year period allows us to look for any trends in the characteristics of students enrolled in an economics course. We restrict the focus of this paper to two courses: principles of microeconomics and intermediate microeconomics. All the institutions in our data offer these two courses and this restriction allows us to focus on the findings without the distractions that including many other courses would introduce. We find a significant increase in the fraction of student enrolled in the principles of microeconomics course that are female or part of a minority racial group. We also use the data to examine the selection of students into the economics major and the performance of students in intermediate microeconomics by major.

\section{Description of the MIDFIELD Institutions}

The National Science Foundation provided the funding for the creation of the MIDFIELD database. It was created in 1996 (under the name SUCCEED) and has grown as additional years of data have been added and as additional institutions have joined. In this paper we use the undergraduate academic records from Clemson, Florida State, Georgia Tech, North Carolina State, Purdue, University of Florida, University of North Carolina at Charlotte, and Virginia Tech.

We do not have complete records from all institutions for all years in our study (1990-2003) so we drop certain institutions for some portions of the analysis. 
Each of the universities has a large engineering school as well as a business school and at each university economics is a small major. Only about 1 percent of all students in the data are economics majors. However, consistent with Bosshardt and Watts (2008) and Siegfried (2000), about half of all undergraduate students takes at least one economics course. Each of the universities in this study has a two-semester principles sequence with both microeconomics and macroeconomics principles courses offered. Each of these universities also has (or had) a combined one-semester economics principles course for non-majors. Enrollment in this onesemester economic principles course (called "economic concepts" at some institutions) has declined at all the universities in this study and has been discontinued at some.

\section{Time Trends in the Characteristics of Students in Economics Courses}

Has the number of students enrolled in economics courses changed over the 1990-2003 time period? The answer is yes, as shown in Table 1 which reports the number of students enrolled in the principles of microeconomics course at those universities for which we have complete data for the time period. There was a large increase in enrollment in the principles of microeconomics course with most of the increase coming after 1995. The large increase in enrollment is partly due to a shift away from the one-semester economic concepts course at some of these institutions. However, the primary factor driving the increase in economics enrollment is likely the increase in total undergraduate enrollment at these institutions. 
Table 1 also shows that over this 14 -year period the fraction of female students increased by about 4 percentage points or about 10 percent. The fraction of Hispanic students increased by an enormous 140 percent and the fraction of Asian students increased by about 50 percent. The fraction of black students increased by about 20 percent. However, all but one of the universities in this study are located in the South, so the trends found here may not be representative of the overall trends in the U.S.

The average SAT score increased by more than 10 percent while the average grade (reported on a 4.0 scale) increased from a C+ to a B- in the principles of microeconomics course. This could be evidence of an increase in the ability level of university students, or better selection of students into economics course, or simply grade inflation in both the SAT and course grades. These trends were similar at each university individually.

\section{Selection of Students into the Economics Major}

Some students have already declared themselves as economics majors before they take their first course in economics at the university. In Tables 2 and 3, the heading "economics major" indicates that these students are economics majors at the time they take the principles of microeconomics course. Table 2 indicates that the economics majors are better at economics than the average student in the course; econ majors earn a B- on average while the average student in the course earns a $\mathrm{C}+$. However, the students who have already declared as econ majors at the time they take the econ principles course are not of higher ability (not statistically different) than the average student in the class as measured by SAT/ACT score or 
high school percentile (lower number implies higher ability). Of these econ majors, about 69 percent graduate from the university in 6 years or less, and only 5 percent graduate in a major other than economics (a very high major retention rate).

The largest groups of students who take the principles of microeconomics course are business majors. They tend to do worse than the econ majors and are of lower ability as measured by SAT/ACT score and high school percentile on average. The group of students in the math-intensive STEM majors (science technology, engineering, or math) are of significantly higher ability, particularly in math, but perform slightly worse in the principles of microeconomics course than the economics students on average.

About 40 percent of students who graduate with a major in economics declared their major sometime after completing the principles of microeconomics course. About 40 percent of the students who switch into the economics major after having completed the principles course come from a STEM major. The STEM majors initially attract students of much higher ability than economics as indicated by SAT/ACT score and high school percentile, particularly in the SAT math score and the first-year of coursework in STEM majors generally requires more math than the first-year coursework in economics.

So, it could be that STEM majors that switch into economics are of higher ability and better trained in mathematics and therefore outperform the initial economics majors. Or, it could be that the students who switch into economics are those students who performed very poorly in their STEM major and need some less difficult major to switch to. However, using an earlier version of this same dataset, Ohland et al. (2004) claim that poor performance is not the 
primary reason students leave engineering. They do find strong evidence that those students who have a low GPA when they leave their STEM major are more likely to switch into a major in business or management. Economics is not separated out as a destination for STEM majors in this earlier work, so we will address that here.

As shown in Table 3, we find that those students who start as a STEM major and graduate as an economics major performed significantly worse in their STEM major than other STEM major students who also took the principles of microeconomics course and graduated in a STEM field. This is indicated by a 0.50 grade point average difference at the time they first take the principles of microeconomics course. In addition, those students who switch from a STEM major and graduate in economics do not perform as well in principles of microeconomics as those students who graduate in a STEM field. There seems to be more of a push out of STEM fields into something easier than a pull into economics. However, note the STEM students who switch into economics do have significantly higher SAT math scores than other economics majors. It is also interesting to note that female STEM students are much less likely to switch into economics than male STEM students.

\section{Performance of Students in Intermediate Microeconomics by Major}

The level of mathematics required for the intermediate microeconomics course is much higher than that required for the principles of microeconomics course. The economics major typically only requires a passing grade in calculus where STEM majors are required to take additional math. Therefore, it is possible that students who start out as STEM majors are better 
prepared for the intermediate-level economics courses than those students who start out in economics.

In Table 4, we show the fraction of students who receive each letter grade in the intermediate microeconomics course separated by the letter grade received in the principles of microeconomics course. As expected, the data shows that students who received a higher grade in principles of microeconomics perform better in the intermediate microeconomics course. However, the STEM majors who switch into economics do not perform any better than those students who were already econ majors at the time they took the principles of microeconomics course. In fact, for only those students who received an A in the principles of microeconomics course, the STEM majors perform worse than the econ majors on average, although the difference is not statistically significant ( $t$-stat $=0.1247$ ).

This suggests that the training received by economics majors on average before taking intermediate microeconomics is at least as good as the training received by STEM majors who later switch to econ majors. Recall that these students have very similar ability levels as documented in Table 3 with the exception that the students who switch from STEM to economics have higher SAT math scores on average. However, in results not shown in Table 4, STEM majors who take intermediate micro and graduate in a STEM field outperform both the economics majors and the students who switch from STEM to economics by a substantial (and statistically significant) margin. 


\section{Conclusion}

Our results quantify some interesting patterns in undergraduate economics coursework. The primary contribution of this paper is that we present a more complete picture of the characteristics and performance of undergraduates who take economics courses than was previously available. One of the main findings is that the fraction of students in economics courses that are female or minorities increased over the study period. Another is that economics majors are not, on average, of higher or lower ability than other students who take the principles of microeconomics course. However, economics majors outperform these other students, perhaps indicating that they were able to identify their own comparative advantage.

Somewhat surprising to the authors was the finding that those students who switch from a STEM major to the economics major do not perform better in the more math-intensive intermediate microeconomics course, even after controlling for their performance in the principles of microeconomics course.

The MIDFIELD data is a rich dataset that can be used to answer a multitude of additional questions relating to the characteristics and performance of undergraduate students in economics courses. Of particular interest to the authors is an examination of the performance of students in popular field courses such as international, money and banking, public, labor, and econometrics. We leave this work to a subsequent paper. 


\section{References}

Allgood, Sam, William Bosshardt, Wilbert Van Der Klaauw, and Michael Watts (2004) "What Students Remember and Say about College Economics Years Later" American Economic Review Papers and Proceedings, 94(2) May 2004, 259-265

Bosshardt, William and Michael Watts (2008) “Undergraduate Students' Coursework in Economics" Journal of Economic Education, 39(2) April 2008, 198-205.

Dynan, Karen E. and Cecilia Elena Rouse (1997) "The Underrepresentation of Women in Economics: A Study of Undergraduate Economics Students" Journal of Economic Education, 28(4), 350-368.

Jensen, Elizabeth J. and Ann L. Owen (2000) "Why are Women Such Reluctant Economists? Evidence from Liberal Arts Colleges" American Economic Review, 90(2), 466-470.

Ohland, Matthew W., Guili Zhang, Brian Thorndyke, and Timothy J. Anderson (2004) "GradePoint Average, Changes of Major, and Majors Selected by Students Leaving Engineering" Proceedings of the $34^{\text {th }}$ ASEE/IEEE Frontiers in Education Conference, T1G-12.

Salemi, Michael K. and Carlie Eubanks (1996) "Accounting for the Rise and Fall in the Number of Economics Majors with the Discouraged-Business-Major Hypothesis" Journal of Economic Education, 27 (4) Fall 1996, 350-361.

Siegfried, John J. (2000) "How Many College Students Are Exposed to Economics?" Journal of Economic Education, 31(2) Spring 2000, 202-204. 


\section{Tables}

Table 1: Students Enrolled in Principles of Microeconomics

\begin{tabular}{|c|c|c|c|c|c|c|c|}
\hline Year & $\begin{array}{c}\text { Micro } \\
\text { Principles } \\
\text { Enrolment }\end{array}$ & $\begin{array}{l}\text { Percent } \\
\text { Female }\end{array}$ & $\begin{array}{l}\text { Percent } \\
\text { Hispanic }\end{array}$ & $\begin{array}{c}\text { Percent } \\
\text { Black }\end{array}$ & $\begin{array}{c}\text { Percent } \\
\text { Asian }\end{array}$ & $\begin{array}{c}\text { SAT } \\
\text { Score }\end{array}$ & $\begin{array}{c}\text { Course } \\
\text { Grade }\end{array}$ \\
\hline 1990 & 7,580 & .387 & .028 & .061 & .042 & 1062.2 & 2.54 \\
\hline 1991 & 6,972 & .381 & .028 & .068 & .045 & 1064.8 & 2.57 \\
\hline 1992 & 6,328 & .369 & .039 & .064 & .050 & 1066.2 & 2.59 \\
\hline 1993 & 6,881 & .377 & .047 & .059 & .048 & 1066.5 & 2.61 \\
\hline 1994 & 7,601 & .379 & .051 & .057 & .054 & 1066.0 & 2.74 \\
\hline 1995 & 8,118 & .384 & .049 & .064 & .050 & 1064.1 & 2.66 \\
\hline 1996 & 9,098 & .397 & .051 & .060 & .055 & 1088.0 & 2.71 \\
\hline 1997 & 9,941 & .401 & .055 & .056 & .056 & 1123.9 & 2.68 \\
\hline 1998 & 9,914 & .400 & .049 & .059 & .059 & 1143.7 & 2.73 \\
\hline 1999 & 10,494 & .393 & .051 & .063 & .060 & 1157.4 & 2.66 \\
\hline 2000 & 10,978 & .406 & .055 & .067 & .060 & 1168.1 & 2.77 \\
\hline 2001 & 11,695 & .424 & .060 & .069 & .060 & 1177.3 & 2.82 \\
\hline 2002 & 11,047 & .425 & .068 & .072 & .062 & 1185.9 & 2.86 \\
\hline 2003 & 12,278 & .422 & .069 & .075 & .065 & 1192.2 & 2.74 \\
\hline
\end{tabular}

Notes: The data includes all students enrolled in Principles of Microeconomics at Clemson, Florida State, North Carolina State, Purdue, University of Florida, and Virginia Tech from 1990 - 2003. 
Table 2: Students Enrolled in Principles of Microeconomics

\begin{tabular}{|c|c|c|c|c|c|}
\hline & $\begin{array}{c}\text { All } \\
\text { Students }\end{array}$ & $\begin{array}{c}\text { Econ } \\
\text { Majors }\end{array}$ & $\begin{array}{c}\text { Business } \\
\text { Majors }\end{array}$ & $\begin{array}{l}\text { STEM } \\
\text { Majors }\end{array}$ & $\begin{array}{c}\text { Econ } \\
\text { Graduates }\end{array}$ \\
\hline Number of Students & 197,646 & 2,810 & 65,147 & 58,993 & 2,963 \\
\hline Course Grade (4.0 scale) & 2.58 & 2.86 & 2.57 & 2.79 & 2.91 \\
\hline Female & .396 & .274 & .441 & .292 & .255 \\
\hline Black & .079 & .087 & .087 & .071 & .071 \\
\hline Hispanic & .043 & .035 & .045 & .036 & .030 \\
\hline Asian & .059 & .046 & .049 & .073 & .052 \\
\hline Freshman & .371 & .396 & .370 & .359 & .392 \\
\hline Sophomore & .445 & .458 & .526 & .380 & .462 \\
\hline Junior & .129 & .116 & .090 & .163 & .117 \\
\hline Senior & .056 & .030 & .014 & .098 & .029 \\
\hline High School Percentile & 25.2 & 24.8 & 26.0 & 23.4 & 24.6 \\
\hline SAT Verbal Score & 524.9 & 528.2 & 516.0 & 532.0 & 525.5 \\
\hline SAT Math Score & 582.4 & 580.0 & 569.8 & 611.3 & 583.4 \\
\hline ACT Score & 24.7 & 25.0 & 24.1 & 26.1 & 25.3 \\
\hline Graduate in 6 years & .615 & .687 & .634 & .662 & 1 \\
\hline Graduate in Economics & .015 & .638 & .007 & .008 & 1 \\
\hline
\end{tabular}

Notes: The STEM majors include science, technology, engineering, and math. The data includes all students enrolled in Principles of Microeconomics at Clemson, Florida State, North Carolina State, Purdue, UNC Charlotte, University of Florida, and Virginia Tech from 1990 - 2003. Students from Georgia Tech are included for years 19992003. 
Table 3: Students Enrolled in Micro Principles by Current and Graduation Major

\begin{tabular}{|c|c|c|c|c|}
\hline & \multicolumn{2}{|c|}{ STEM Major } & \multirow{2}{*}{$\begin{array}{c}\text { Econ Major } \\
\text { Econ } \\
\text { Graduate }\end{array}$} & \multirow{2}{*}{$\begin{array}{c}\text { Other Major } \\
\text { Econ } \\
\text { Graduate } \\
\end{array}$} \\
\hline & $\begin{array}{c}\text { STEM } \\
\text { Graduate }\end{array}$ & $\begin{array}{c}\text { Econ } \\
\text { Graduate }\end{array}$ & & \\
\hline Number of Students & 29,710 & 466 & 1,794 & 703 \\
\hline Course Grade ( 4.0 scale) & 3.10 & 2.89 & 2.95 & 2.81 \\
\hline Female & .267 & .197 & .273 & .250 \\
\hline Black & .047 & .079 & .079 & .044 \\
\hline Hispanic & .029 & .024 & .030 & .034 \\
\hline Asian & .073 & .047 & .042 & .081 \\
\hline Freshman & .278 & .384 & .384 & .420 \\
\hline Sophomore & .357 & .433 & .467 & .470 \\
\hline Junior & .203 & .148 & .116 & .097 \\
\hline Senior & .161 & .034 & .033 & .014 \\
\hline Cumulative GPA & 2.96 & 2.47 & 2.78 & 2.58 \\
\hline High School Percentile & 22.8 & 24.8 & 24.3 & 25.4 \\
\hline SAT Verbal Score & 526.7 & 524.8 & 526.3 & 524.1 \\
\hline SAT Math Score & 624.0 & 600.0 & 579.5 & 581.2 \\
\hline ACT Score & 26.6 & 26.1 & 25.2 & 25.1 \\
\hline Graduation GPA & 3.00 & 2.63 & 2.86 & 2.77 \\
\hline $\begin{array}{l}\text { Notes: The STEM majors inclu } \\
\text { all majors other than STEM } \\
\text { Microeconomics at Clemson, } \\
\text { Virginia Tech from } 1990-200\end{array}$ & $\begin{array}{l}\text { ce, technolo } \\
\text { and econon } \\
\text { tate, North }\end{array}$ & $\begin{array}{l}\text { engineering } \\
\text {. The data } \\
\text { lina State, }\end{array}$ & $\begin{array}{l}\text { h. The 'other } \\
\text { all students } \\
\text { NC Charlotte, } \\
\text { r years 1999-2 }\end{array}$ & $\begin{array}{l}\text { ategory includes } \\
\text { in Principles of } \\
\text { y of Florida, and }\end{array}$ \\
\hline
\end{tabular}


Table 4: Student Performance in Intermediate Microeconomics

\begin{tabular}{|c|c|c|c|c|c|c|}
\hline \multicolumn{7}{|c|}{ Panel A: All Students } \\
\hline \multirow{2}{*}{$\begin{array}{l}\text { Micro Principles } \\
\text { Course Grade }\end{array}$} & \multicolumn{6}{|c|}{ Intermediate Microeconomics Grade } \\
\hline & $A$ & B & $\mathrm{C}$ & $\mathrm{D}$ & $\mathrm{F}$ & Average \\
\hline$A$ & .474 & .343 & .131 & .030 & .022 & 3.23 \\
\hline B & .170 & .379 & .304 & .088 & .059 & 2.52 \\
\hline $\mathrm{C}$ & .090 & .297 & .378 & .148 & .086 & 2.17 \\
\hline $\mathrm{D}$ & .080 & .244 & .359 & .184 & .132 & 1.95 \\
\hline
\end{tabular}

Panel B: Economics Graduates that were Econ Majors

\begin{tabular}{|c|c|c|c|c|c|c|}
\hline \multirow{2}{*}{$\begin{array}{l}\text { Micro Principles } \\
\text { Course Grade }\end{array}$} & \multicolumn{6}{|c|}{ Intermediate Microeconomics Grade } \\
\hline & $A$ & B & $\mathrm{C}$ & $\mathrm{D}$ & $\mathrm{F}$ & Average \\
\hline A & .452 & .376 & .127 & .033 & .013 & 3.23 \\
\hline B & .144 & .388 & .349 & .082 & .037 & 2.52 \\
\hline $\mathrm{C}$ & .100 & .363 & .390 & .096 & .050 & 2.35 \\
\hline $\mathrm{D}$ & .050 & .225 & .450 & .150 & .125 & 1.87 \\
\hline
\end{tabular}

Panel C: Economics Graduates that were STEM Majors

\begin{tabular}{|c|c|c|c|c|c|c|}
\hline \multirow{2}{*}{$\begin{array}{l}\text { Micro Principles } \\
\text { Course Grade }\end{array}$} & \multicolumn{6}{|c|}{ Intermediate Microeconomics Grade } \\
\hline & $A$ & B & $\mathrm{C}$ & $\mathrm{D}$ & $\mathrm{F}$ & Average \\
\hline A & .409 & .336 & .208 & .027 & .020 & 3.10 \\
\hline B & .147 & .412 & .319 & .049 & .074 & 2.52 \\
\hline $\mathrm{C}$ & .077 & .324 & .387 & .134 & .077 & 2.20 \\
\hline $\mathrm{D}$ & .056 & .333 & .333 & .056 & .222 & 1.96 \\
\hline
\end{tabular}

Notes: The STEM majors include science, technology, engineering, and math. The data includes all students enrolled in Intermediate Microeconomics at Clemson, Florida State, Georgia Tech, North Carolina State, Purdue, UNC Charlotte, University of Florida, and Virginia Tech from 1990 - 2003. 